\title{
On Teacher's Roles in Developing Learner Autonomy
}

\author{
Hong-mei ZHAO \\ School of Foreign Languages, Chongqing University of Technology, Chongqing, China
}

\author{
Keywords: Teacher's Roles; Learner Autonomy; Strategies.
}

\begin{abstract}
How to motivate and cultivate learners toward independent and autonomous learning becomes the focus of the present teaching, foreign language teachers have been witnessed to play a great important role in facilitating or fostering learner autonomy. This essay aims to do what little one can do by exploring teachers' roles in developing learner autonomy and strategies that teachers should involve in the process of autonomous learning so as to foster learners' autonomy. The author suggests that teachers should give students specific training in learner autonomy on the basis of needs analysis, facilitate them to keep on learning in the whole process of autonomous learning, and develop suitable materials which are catering to students' autonomous learning. Teachers also need to pay special attention to continuous self-development so as to become an expert as well as a friend to learners.
\end{abstract}

\section{Introduction}

Since the concept of learner autonomy was introduced into the field of foreign language teaching, English teachers and scholars across the world frequently debate the issue of learner autonomy or autonomous learning, which is a popular trend in education, especially for second or foreign language learners. As a significant social agent who shapes the quality of students' intellectual and social experiences [1], the teacher has a critical role to play in helping students to exert autonomy both inside and outside classroom $[2,3,4]$. Consequently, teachers should clearly know the strategies how to play their roles in developing learner autonomy while doing teaching or guiding in-class and out-of-class. A major part of implementing autonomy in-class and out-of-class is to instruct various strategies, and assist students in finding the most suitable methods for them. Meanwhile, little attention has been paid to how teachers fulfill their roles strategically in developing learners' autonomy inside and outside classroom. Thus, this essay aims to enrich our understanding of the roles that teachers should act in promoting learner autonomy, and of the roles that teachers are aware of they are expected to play, and of the strategies that teachers involve in the process of autonomous learning so as to foster learner autonomy.

\section{Literature Review}

\subsection{The Definition of Learner Autonomy}

There exists a wide range of discussion or literature about the definition of learner autonomy from different perspectives by different experts or scholars. Some scholars define autonomy as a kind of ability, some define it as a process of learning, some others define it as teaching practice, and still others define it as a kind of political concept. Actually, the concept of autonomous learning can be traced back to more than 50 years ago, which was in 1960 s, there were debates about the development of independent thinkers and the development of life-long learning skills. By 1981, the definition of autonomy was first introduced into the educational field by Holec [5], who is considered a father of autonomous learning, he described it as "the ability to take charge of one's own learning". He also mentioned that this ability "is not inborn but must be acquired by "natural" means or (as most often happens) by formal learning, i.e. in a systematic, deliberate way", and pointed out that "to take charge of one's own learning is to have ... the responsibility for all the decisions concerning all aspects of learning ..." Holec's definition about autonomy has exerted huge influence on autonomy research and has been thought of as a beginning for subsequent relevant research. 


\subsection{Teacher's Role in Autonomous Learning Context}

With the increasingly applying the concept of learner autonomy into the practice, teachers' roles or involvement in autonomous language learning are confronting with new considerations or challenges. Learner autonomy serves both as a mean and the end of language teaching, which places much emphasis on developing learner autonomy as one of educational goals. Teacher's role is both necessary and significant to guarantee and enhance or promote learner autonomy and for that reason can never and forever be neglected. Teachers' in-class autonomy support behaviors can boost students' willingness to engage in autonomous learning outside the classroom [6]. Without teacher's guidance and supervision, the total autonomous learning process will lead to low efficiency and even fall into disorder. "I believe that all truly effective learning entails the growth of autonomy in the learner as regards both the process and the content of learning; but I also believe that for most learners the growth of autonomy requires the stimulus, insight and guidance of a good teacher" [7]. Autonomous learning is not necessarily learning alone, nor is it necessarily learning without a teacher.

\section{Roles a Teacher Should Act as in Developing Learner Autonomy}

With the more communicatively learner-centered teaching mode becoming the major teaching trend, teachers are transforming their traditional unidirectional role as knowledge purveyor into the active participants, monitors, consultants and guides. They transform themselves into helpers and facilitators [8]. According to some experts' research of learner autonomy, and considering the high demand for teachers' support and different ways teachers could provide support, in general, teachers are supposed to play the following 11 roles in promoting learner autonomy in-class and out-of-class.

(1) A facilitator to develop students' self-confidence, arouse students' interest, keep students' enthusiasm in autonomous learning.

(2) A trainer or a guide to teach students various strategies of learner autonomy and guide students to do autonomous learning.

(3) A counselor or an advisor to offer reasonable and feasible suggestions to help students find most suitable learning strategies and help students seek for best solution to their problems.

(4) An instructor to state explicitly to students teaching plan, teaching requirements, teaching contents and even teaching focus and difficulties so as to ensure students know teacher's expectations clearly at all times.

(5) A resource provider to provide ample knowledge, information, and materials to satisfy students' needs, and to promote and improve students.

(6) A coordinator or organizer to build up a kind of relaxing and harmonious atmosphere and create a lot of opportunities for students to try them out in diverse circumstances.

(7) A cooperator or peer learner to act as a peer learner to establish a close collaboration and constructive interaction with students so as to learn from each other.

(8) An assessor to give punctual and appropriate praise, feedback and guidance to students' finished project and progress.

(9) A monitor to monitor students' whole learning process like learning methods, learning contents, learning progress, and something like that, and try to find their strong and weak points.

(10) A researcher to conduct deep research into the techniques of teaching, autonomous learning strategies, and students so as to implement effective and efficient autonomy during teaching.

(11) A developer of teaching materials to develop sustainable and suitable teaching materials with different difficulties and contents in accordance with students' English proficiency and individual needs.

Through all the above analysis, a great deal of information have been obtained about teachers' specific roles in developing learner autonomy. 


\section{Strategies Teachers Involve in the Process of Autonomous Learning}

The following discussion will be conducted in the hope of answering how teachers should do to involve in learner autonomy so as to promote learner autonomy in and out-of-class effectively and efficiently.

\subsection{Be a Qualified Trainer by Giving Students Specific Training in Autonomous Learning}

The following aspects should be included in the training program: how to do self-assessment of their learning ability, and their language ability, how to set their learning goals, how to do decision-making; how to do problem solving by them; how to do self-control and correction of deviation; how to manage time, and so on.

\subsection{Be an Excellent Counselor}

There are definitely various needs, questions and problems arisen from students. Firstly, a teacher should know how to do needs analysis of students, including students' learning goals, attitudes, methods, ability, experiences, and so on. Secondly, a teacher should know how to be a competent teacher, including a good command of language, techniques of language teaching and language learning, the situation of students' learning, the social requirements for students, and the ways to attain students' goals.

\subsection{Be an Outstanding Facilitator so as to Help Students to Keep their Motivation and Interest in Autonomous Learning}

Firstly, a teacher should know how to monitor students by properly using monitoring, properly control the degree of monitoring. Secondly, a teacher should know how to assess students appropriately, effectively, and efficiently; a good teacher should attach great weight to the degree, otherwise, things will go contrary to one's wishes. Effective feedback comes from proper monitoring and assessment, they are mutually promoted. Finally, a teacher should know how to exert his or her influences on students. An expert should be good at taking full advantage of his / her own influences to arouse the enthusiasm of students so as to keep students' initiatives and interest in learner autonomy.

\subsection{Be a Nice Developer of Teaching Materials by Developing the Most Suitable and Sustainable Materials for Learners}

This kind of teaching materials should take the following factors into account: learners' individual differences in language proficiency and learning ability, learners' language learning objectives or goals, ample cyber resources, a criterion for students to do self-assessment, updating contents with times and changes.

\section{Summary}

Teachers take major responsibility for fostering leaner autonomy in language learning process. Teachers need to adjust their roles appropriately: on the one hand, teachers should prevent students from developing new reliance, and attach added importance to facilitating and guidance instead of replacing. On the other hand, teachers should become students' good friends and teachers, and keep on lifelong learning and lifelong self-improvement. Do remember that the premise of students' autonomous development is teachers' self-directed development.

\section{Acknowledgement}

This research was financially supported by the Educational Reform Project in Chongqing University of Technology (No. 2017ZDJG05) and the Educational Reform Project of Chongqing Municipal Education Commission (No. 182019). 


\section{References}

[1] H.A. Davis, Conceptualizing the role and influence of student-teacher relationships on children's social and cognitive development. Educational Psychologist, 2003, 38: 207- 234.

[2] N. Lazaro, H. Reinders, Language learning and teaching in the self-access center: A practical guide for teachers. Sydney, Australia: NCELTR, 2009.

[3] D. Little, Constructing a theory of learner autonomy: Some steps along the way. Oulu: Publications of the Faculty of Education in Oulu University 101, 2004.

[4] D. Toffoli, G. Sockett, University teachers' perceptions of online informal learning of English (OILE). Computer Assisted Language Learning, 2015, 28 (1): 721.

[5] H. Holec, Autonomy in Foreign Language Learning. Oxford: OUP, 1981.

[6] M.S. Hagger, N.L.D. Chatzisarantis, Transferring motivation from educational to extramural contexts: A review of the trans-contextual model. European Journal of Psychology and Education, 2012, 27: 195.

[7] D. Little, Why focus on learning rather than teaching? The International Association of Teachers of English as a Foreign Language, 2000.

[8] A.L. Wenden, Learner Strategies for Learner Autonomy: Planning and Implementing Learner Training for Language Learners. Prentice-Hall International, Hertfordshire, UK, 1991.

[9] D. Little, Learning as dialogue: the dependence of learner autonomy on teacher autonomy. System 1995, 23 (2): 175-181. 